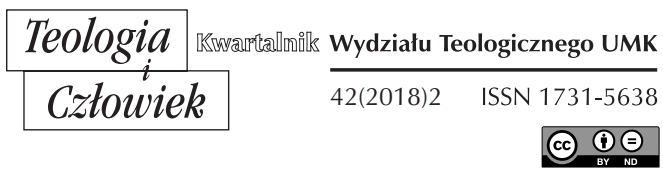

KS. SŁAWOMIR TYKARSKI*

TORUŃ

ORCID: 0000-0002-3854-552X

\title{
DEZYDERATY PRZEŻYCIA WIELKIEGO POSTU WEDŁUG ŚW. SIOSTRY FAUSTYNY
}

DOI: http://dx.doi.org/10.12775/TiCz.2018.019

Okres Wielkiego Postu to szczególny czas, jaki daje Kościół. Podczas niego wierni podejmują postanowienia, wyrzeczenia i wysiłek pracy nad sobą. Często wyrzeczenia odnoszą się do wymiaru materialnego: odmówienie sobie przyjemności, ograniczenie posiłku czy oglądania telewizji. Inna forma odnosi się do wymiaru duchowego, który wiąże się między innymi z pracą nad własnymi wadami, niedoskonałościami charakteru bądź pogłębieniem życia duchowego ${ }^{1}$. Praktyka duszpasterska

* Ks. dr Sławomir Tykarski jest adiunktem w Katedrze Teologii Praktycznej Wydziału Teologicznego UMK (tykarek@gmail.com).

1 Zagłębiając się w tematykę, można pokusić się o stwierdzenie, że postanowienia duchowe mają głębszy wymiar niż materialne. Nie oznacza to, że materialne są mniej ważne bądź łatwiejsze w realizacji - jest to raczej sprawa subiektywna, związana z konkretną osobą. Niemniej często zdarza się, iż postanowienia materialne zostają zawieszone wraz z końcem Wielkiego Postu, natomiast duchowe trwają nadal, na przykład ktoś dalej pracuje nad poprawą własnego zachowania. Dziwne by było, gdyby przez okres Wielkiego Postu osoba była uprzejma, a po skończonym okresie pokutnym znów powróciła do swojego dawnego zachowania i brnęła w nieuprzejmość. 
wskazuje, że niekiedy wiernym brakuje pomysłów, w jaki sposób spożytkować i dobrze wykorzystać czas Wielkiego Postu. Celem niniejszego rozważania jest podanie wskazówek i propozycji do jego przeżycia na podstawie przykładu św. Siostry Faustyny, która podczas życia zakonnego przeżyła ten okres trzynaście razy. Kilka z nich w sposób fragmentaryczny opisała w swoim „Dzienniczku”, który posłuży jako źródło dla poniższego opracowania. Zostanie w nim przedstawione siedem głównych dezyderatów, które niekiedy składają się z kilku elementów.

\section{MODLITWA, ADORACJA I DZIELENIE SIĘ Z BOGIEM CODZIENNOŚCIĄ}

W Wielkim Poście Siostra Faustyna uczyniła postanowienie, że codziennie przez pół godziny będzie adorować Najświętszy Sakrament $(\mathrm{Dz} 147)^{2}$. Jak twierdzi, w tym czasie otrzymała najwięcej światła od Boga.

Należy również zaznaczyć, że niniejsze propozycje przeżywania Wielkiego Postu na podstawie życia św. Siostry Faustyny nie muszą być wykonywane wyłącznie w tym okresie liturgicznym. $\mathrm{Z}$ powodzeniem mogą być realizowane $\mathrm{w}$ ciągu całego roku.

2 „Przypominam sobie, że najwięcej światła otrzymałam w adoracji, które odprawiałam codziennie przez pół godziny przez cały post przed Najświętszym Sakramentem, leżąc krzyżem. W tym czasie poznałam głębiej siebie i Boga. Pomimo że miałam wiele przeszkód do odprawienia takiej modlitwy, pomimo że miałam pozwolenie przełożonych. Niech dusza wie, że aby się modlić i wytrwać w modlitwie, musi się uzbroić w cierpliwość i mężnie pokonywać trudności zewnętrzne i wewnętrzne. Trudności wewnętrzne - zniechęcenie, oschłość, ociężałość, pokusy; zewnętrzne - wzgląd ludzki i uszanować chwile, które są przeznaczone na modlitwę. Sama tego doświadczyłam, że jeżeli nie odprawiłam modlitwy w czasie dla niej przeznaczonym, później już jej nie odprawiłam, bo mi obowiązki nie pozwoliły, a jeżeli ją odprawiłam, to z wielkim trudem, myśl ucieka do obowiązku. Zdarzała mi się ta trudność, że jeżeli dusza dobrze odprawiła modlitw i wyszła z niej z wewnętrznym, głębokim skupieniem, inni sprzeciwiają jej się w tym skupieniu, a więc musi być cierpliwość, aby wytrwać w modlitwie. Zdarzała mi się rzecz taka niejednokrotnie, że kiedy dusza moja była głębiej pogrążona w Bogu i większy owoc odniosła z modlitwy i obecność Boga towarzyszyła w ciągu dnia, a przy pracy było większe skupienie i większa dokładność i wysiłek w obowiązku, - to jednak zdarzało mi się, że właśnie wtenczas najwięcej miałam upomnień, że jestem nieobowiązkowa, że jestem obojętna na wszystko, bo dusze mniej skupione chcą, aby i inni byli im podobnie, ponieważ są dla nich ustawicznym wyrzutem” (Dz 147). 
Adoracje te były szczególne w formie, odprawiała je bowiem, leżąc krzyżem. Co taka modlitwa dała Faustynie? Jak sama mówi, „w tym czasie poznałam głębiej siebie i Boga”. To stwierdzenie może posłużyć jako główny motyw sposobu przeżycia Wielkiego Postu, czyli głębokie poznanie Boga i siebie. Można zatem zadać pytanie: na czym polega poznanie siebie? To samoświadomość i wgląd w swoje myśli, uczucia, motywy zachowań. To panowanie nad tym, co się mówi, jak reaguje. Głębsze poznanie siebie jest konieczne w dążeniu do doskonałości, wyostrza bowiem czujność wobec pokus do złego. Dzięki znajomości własnego funkcjonowania człowiek może ustrzec się przed grzechem i nie narażać się na jego popełnienie. Ponadto poznanie siebie jest konieczne do zmian swoich zachowań, do pracy nad wadami charakteru czy niedoskonałościami. Jeśli osoba nie potrafi nazwać, zdiagnozować, co się w niej dzieje i dlaczego, to trudno jej będzie znaleźć właściwe środki naprawcze. W związku z tym czas Wielkiego Postu staje się szansą na przyjrzenie się sobie. Co więcej, inne osoby mogą w tym pomóc poprzez zwrócenie uwagi, co zauważyły niepokojącego w zachowaniu danego człowieka. Oczywiście taki szczery dialog wymaga dojrzałości obu stron - osoby zainteresowanej, która będzie potrafiła z cierpliwością i spokojem przyjąć prawdę o sobie, a także osoby, która będzie zwracać uwagę, nie wywyższając się i nie czyniąc przykrości.

Natomiast głębsze poznanie Boga to budowanie z Nim żywych relacji. Aby sprawdzić, czy takie są, warto zwrócić uwagę na to, czy po czterdziestu dniach Wielkiego Postu będzie się potrafiło coś więcej powiedzieć o Bogu niż do tej pory. Czy będzie się wiedziało, czego wymaga Bóg? Czy realizuje się Jego wolę, jaką ma odnośnie do życia danej jednostki? Czy relacje z Nim traktuje się analogicznie do relacji z osobami bliskimi? Z rodziną bądź przyjaciółmi często się rozmawia, spotyka, przeprasza, gdy się zawini przeciwko nim, dotyka, przytula, obejmuje ramieniem. Warto postawić sobie pytania dotyczące relacji do Boga. Czy rozmawia się z Nim na osobistej modlitwie i poprzez rozważanie słowa Bożego? Czy się Go odwiedza podczas niedzielnej Eucharystii bądź krótkich nawiedzeń w świątyni w ciągu tygodnia? Czy przeprasza się Go w konfesjonale, gdy zawini się przeciwko Niemu. Kiedy podejmuje się spowiedź? Jak najszybciej po popełnieniu grzechu ciężkiego czy raczej po kilku miesiącach, „przy okazji” podczas spowiedzi wielkanocnej (zazwyczaj osoby bliskie przeprasza się jak najszybciej)? Czy dotyka się Go 
w Eucharystii? Warto przyjmować Komunię ze świadomością, iż dotyka się tego samego Jezusa, który uzdrawiał, wskrzeszał umarłych, leczył na duchu, o czym świadczą słowa Ewangelii.

Głębokie relacje z Bogiem kształtuje się również przez odnajdywanie Go w prozie codzienności i zapraszanie do spraw związanych ze zwyczajną egzystencją. Obrazuje to pewne zdarzenie z życia św. Faustyny: „Faustyna ze wszystkimi sprawami, również takimi jak prace kuchenne, zwracała się do Jezusa. Rozmawiała z Nim jak z Panem i najlepszym przyjacielem. Ufała Mu bezgranicznie. Siostra Placyda wspominała, że pewnego dnia, latem, były w kuchni tylko we dwie. Główna kucharka zachorowała. Akurat przywieziono do kuchni pół krowy. «Ja byłam zmartwiona: co to będzie, taki upał, tu tyle mięsa przywieziono. Siostra Faustyna powiedziała: «niech się siostra nie martwi, pójdę do kaplicy i zapytam Pana Jezusa, co zrobić. On mi na pewno doradzi». Poszła i gdy wróciła, kazała to co jędrniejsze włożyć do marynaty, a resztę ugotować, by się nie zepsuło. Później siostra dziwiła się, mówiąc: jak ten dzieciak sobie dobrze i mądrze poradził»"3.

Ponadto św. Faustyna nie szczędziła czasu i możliwości mówienia o Bogu i Jego miłosierdziu w zwyczajnych rozmowach i prozaicznych czynnościach. Zamiast rozprawiać o rzeczach mało ważnych lub opowiadać o życiu innych, wybierała tematy rozmów skierowanych na Boga. Jednym $z$ wielu świadectw niech będzie wspomnienie siostry Stelli Kozłowskiej, która wraz z św. Faustyną przebywała na placówce w Wilnie: „Raz w rekreację zbliżyłam się do niej, gdy zbierała groch. Bardzo się spieszyła, więc pomogłam jej, i wtedy rozmawiając $\mathrm{z}$ nią, zdumiona byłam jej porywami, gdy mówiła o Bogu, Jego wielkiej miłości i dobroci dla ludzi. Z grochu wysunęła obraz potęgi i wielkości Bożej, widząc jak ziarenko przekształca się w roślinę, kwiat i owoc. A mówiła to z taką żarliwością, z takim patosem, aż do dziś dnia to czuję. Odniosłam wrażenie, że byłam na dobrym kazaniu czy też konferencji; odtąd zbliżyłam się do niej i często miałyśmy temat do rozmowy"4. Takie zachowanie poświadcza jeszcze inne wspomnienie tej samej siostry. Wydarzyło się to w Krakowie już po przeniesieniu Faustyny z Wilna. Siostra Stella odwiedziła tam Fau-

3 E. K. Czaczkowska, Siostra Faustyna. Biografia Świętej, Kraków 2012, s. 126.

${ }^{4}$ Wspomnienia o świętej Siostrze Faustynie Kowalskiej ze Zgromadzenia Matki Bożej Miłosierdzia, wyd. 2, Kraków 2015, s. 219. 
stynę, która już coraz bardziej chorowała na płuca. Pisze tak: „Przy okazji więc mogłyśmy znów porozmawiać. Tematów dość było, wypytywała się o wszystkich i szczegółowo o jednostki jej bliższe, a zawsze wracała do tematu jej miłego. Rozpalała się wprost, gdy mówiła o Bogu, o Panu Jezusie. Opowiedziałam, że w Wilnie u nas na czterdziestogodzinnym nabożeństwie ksiądz doktor Sopoćko (jej spowiednik) mówił prześlicznie kazanie o miłosierdziu Bożym - ja po raz pierwszy słyszałam na ten temat. Tak była zainteresowana i szczegółowo się pytała, jak, co mówił. Sama wiele mówiła $\mathrm{z}$ takim przejęciem o tym wielkim miłosierdziu Bożym dla grzeszników. Znów byłam zdumiona, jaka to dusza nadzwyczajna ta Siostra Faustyna. Zaprosiła mnie raz do piwnicy, gdzie wkładała ogórki, i tam przeszło przez godzinę po raz ostatni w życiu z nią rozmawiałam"s.

Siostra Faustyna była w stanie rozmawiać o Bogu przy grochu i ogórkach. Jest to wskazówka, by w czasie Wielkiego Postu więcej niż dotychczas skupić się na rozmowie o Panu Jezusie. Nie wstydzić się podejmować takich tematów, nie uciekać od nich, wykorzystywać każdą okazję, a jeśli się uda, to summa summarum różne wątki rozmów sprowadzać do tego jednego - Bożego. Oprócz tego dzielić się z Bogiem zwyczajnymi sprawami dnia, jak to było w przykładzie z marynowanym mięsem. Często uciekać się w duszy do kontaktu z Bogiem i w tej osobistej świątyni przebywać z Nim, nawet jeśli jest sporo obowiązków w danym dniu. Trafne pytanie zadała Faustyna, gdy wraz z siostrą Kajetaną Bartkowiak wsiadała do bryczki i widziała spieszących się ludzi na krakowskich ulicach: „Tak się wszyscy spieszą i ciekawe, czy ktoś myśli o Panu Bogu?”. Wielki Post staje się zatem sposobnością do częstego myślenia o Bogu tam, gdzie się przebywa i czym się zajmuje.

\section{POKONYWANIE TRUDNOŚCI W MODLITWIE I W RELACJACH Z INNYMI}

Druga propozycja przeżycia okresu Wielkiego Postu polega na pokonywaniu trudności $\mathrm{w}$ modlitwie i w relacjach interpersonalnych.

\footnotetext{
5 Tamże, s. 220-221.

6 Tamże, s. 181.
} 
W przytoczonym już wcześniej punkcie 147 „Dzienniczka” św. Faustyna wspomina o trudnościach, na które napotkała podczas modlitwy adoracyjnej i leżenia krzyżem: „Pomimo że miałam wiele przeszkód do odprawienia takiej modlitwy, pomimo że miałam pozwolenie przełożonych. Niech dusza wie, że aby się modlić i wytrwać w modlitwie, musi się uzbroić w cierpliwość i mężnie pokonywać trudności zewnętrzne i wewnętrzne. Trudności wewnętrzne - zniechęcenie, oschłość, ociężałość, pokusy; zewnętrzne - wzgląd ludzki i uszanować chwile, które są przeznaczone na modlitwę. Sama tego doświadczyłam, że jeżeli nie odprawiłam modlitwy w czasie dla niej przeznaczonym, później już jej nie odprawiłam, bo mi obowiązki nie pozwoliły, a jeżeli ją odprawiłam, to z wielkim trudem, myśl ucieka do obowiązku. Zdarzała mi się ta trudność, że jeżeli dusza dobrze odprawiła modlitwę i wyszła $\mathrm{z}$ niej z wewnętrznym, głębokim skupieniem, inni sprzeciwiają jej się $\mathrm{w}$ tym skupieniu, a więc musi być cierpliwość, aby wytrwać w modlitwie".

Święta Faustyna przez przytoczony powyżej fragment ukazuje, ile modlitwa wymaga wysiłku i cierpliwości. Opisaną sytuację można przenieść na szerszą płaszczyznę ludzkiej egzystencji, tzn. na wszelkie formy działalności, podejmowanej pracy i wykonywanych obowiązków. Święta wspomina o dwojakiego rodzaju trudnościach: wewnętrznych i zewnętrznych. Do pierwszej kategorii zalicza: zniechęcenie, oschłość, ociężałość, pokusy. Czas Wielkiego Postu może stać się laboratorium, w którym będzie można ćwiczyć własne wnętrze, pokonując negatywne cechy czy zachowania. Wielki Post staje się możliwością do wewnętrznego zmagania się ze swoim zniechęceniem, oschłością i ociężałością na modlitwie, kiedy targają osobą wszelkie rozproszenia. Pomimo tego nie należy rezygnować z modlitwy, szybko się usprawiedliwiając, że nie ma się zdolności, więc po co próbować - Panu Bogu na pewno taka modlitwa się nie podoba. Wręcz przeciwnie - miłe są Mu ludzkie zmagania i wysiłki podejmowane w celu uświęcenia.

Przytoczony fragment z „Dzienniczka” można również odnieść do relacji interpersonalnych. Wielki Post staje się zachętą do wyeliminowania oschłości w kontaktach z ludźmi. Można to osiągnąć poprzez okazywanie życzliwości, zainteresowania drugą osobą, niepielęgnowanie w sobie urazów, przebaczanie, cierpliwe słuchanie. Warto po każdej rozmowie podziękować Bogu za rozmówcę, ufając, że z jakichś powodów zainicjo- 
wał to spotkanie. Co więcej, warto dla spotkanych osób wypraszać Boże błogosławieństwo. Jako wzór odnalezienia się w trudnych relacjach niech posłużą następujące fragmenty $\mathrm{z}$ „Dzienniczka”:

Dziś odwiedziła mnie pewna świecka osoba, przez którą miałam wielkie przykrości, która nadużyła mojej dobroci kłamiąc wiele rzeczy. W pierwszej chwili, gdy ją zobaczyłam, ścięła mi się krew w żyłach, gdyż stanęło mi wszystko przed oczyma, co przez nią wycierpieć musiałam, choć jednym słowem od nich uwolnić bym się mogła. I przyszła mi myśl, aby jej dać poznać prawdę stanowczo i natychmiast. Ale w jednej chwili stanęło mi miłosierdzie Boże przed oczyma i postanowiłam tak z nią postępować, jakby postąpił Jezus, będąc na moim miejscu. Zaczęłam z nią rozmawiać łagodnie, a kiedy zapragnęła rozmawiać ze mną sam na sam, wtenczas dałam jej jasno poznać jej smutny stan duszy, w sposób bardzo delikatny. Widziałam jej głębokie wzruszenie, choć kryła przede mną. W tej chwili weszła osoba trzecia, a więc rozmowa nasza sam na sam została skończona. Osoba ta prosi mnie o szklankę wody i jeszcze dwie rzeczy inne, a to chętnie jej uczyniłam zadość. Jednak gdyby nie łaska Boża, nie w stanie bym była tak z nią postąpić. Kiedy odeszły, dziękowałam Bogu za łaskę, która mnie wspierała w tym czasie. Wtem usłyszałam te słowa: - Cieszę się, żeś postąpiła jako prawdziwa córka Moja. Bądź zawsze miłosierna, jako Ja miłosierny jestem. Kochaj wszystkich z miłości ku Mnie, choćby największych wrogów, aby się mogło w całej pełni odbić w sercu twoim miłosierdzie Moje (Dz 1694-1695). Gdy mnie znowu odwiedziła pewna osoba, o której wspomniałam już na innym miejscu, kiedy poznałam, że zaczyna brnąć w kłamaniu, dałam jej poznać, że wiem, że kłamie - zawstydziła się niezmiernie i zamilkła. [...] ponieważ musiałam się przezwyciężyć, aby z nią rozmawiać na dowód Panu Jezusowi, że kocham nieprzyjaciół, oddałam jej swój podwieczorek (Dz 1712).

Poruszając zagadnienie sztuki komunikacji, nie można pominąć tematu prowadzenia nieszczerych rozmów. Wielki Post stanowi okazję do umartwiania własnego języka, czyli powstrzymywania się od mówienia o innych w sposób niepochlebny, od obmowy i obłudnych zachowań. Faustyna opisuje to w następujący sposób: „W pewnej chwili otrzymałam w duszy światło co do dwóch Sióstr, rozumiałam, że nie ze wszystkimi można postępować jednakowo, są osoby, które dziwnie umieją wejść w przyjaźń i jako przyjaciele, niby w formie ulżenia, wyciągać słówko po 
słówku, a w odpowiedniej chwili używają tych samych słów, aby robić przykrości. Mój Jezu, jak dziwna jest słabość ludzka. Miłość Twoja Jezu, nadaje duszy tę wielką roztropność w stosunku z drugimi” (Dz 695). Tekst ten przestrzega przed przyjmowaniem postawy fałszywych przyjaciół.

Nawiązując do trudności zewnętrznych, które dotyczą braku uszanowania chwil, które osoba przeznacza na modlitwę, można rozumieć to w sposób szerszy, a mianowicie nie zabierać innym prawa do prywatności, wolnej woli i czynienia dobra. Być może Siostrze Faustynie przeszkadzały współsiostry, którym nie podobało się to, że zamiast pracować znajduje czas na adorację. Faustyna podkreśla, że miała na to pozwolenie od przełożonych, niemniej nie uchroniło to jej przed uszczypliwymi komentarzami. Potwierdzają to wspomnienia siostry Felicji Żakowieckiej, która opisuje niniejsze wydarzenie: „Kilka sióstr mówiło o niej, że za dużo się modli w kaplicy, że jest rozpieszczona, że urządziła sobie żywot hrabianki, że nie pojmują takiej doskonałości. Dochodziło to do niej okrężną drogą, ale wzgląd ludzki niewiele ją obchodził, czuło się wyraźnie, że jej chodziło tylko o zadowolenie Pana Jezusa"”. Przytoczona wypowiedź może stać się inspiracją, by osoby wierzące w swoim postępowaniu bardziej szukały sposobów przypodobania się Panu Bogu niż przejmowały się ludzkimi pomówieniami bądź osądami.

\section{WYPRASZANIE NAWRÓCENIE DLA DUSZ}

Kolejną propozycją postanowień wielkopostnych jest wypraszanie nawrócenia dla dusz. Wielki Post nie jest czasem wyłącznej pracy nad sobą w dążeniu do doskonałości. Osobisty rozwój duchowy musi emanować również na relacje $\mathrm{z}$ innymi i przejawiać się $\mathrm{w}$ miłości bliźniego. Przykładem takiej miłości może być wypraszanie nawrócenia dla tych, którzy są daleko od Boga. Siostra Faustyna szczególne wysiłki modlitewne o nawrócenie dusz czyniła w Wielkim Poście: „W pierwszy piątek miesiąca przed Komunią, ujrzałam dużą puszkę napełnioną Hostiami świętymi; jakaś ręka postawiła mi tę puszkę i wzięłam ją w rękę, a było w niej tysiąc Hostii żywych. Wtem usłyszałam głos: Te Hostie są przyjęte

7 Tamże, s. 157. 
przez dusze, którym wyprosiłaś łaskę szczerego nawrócenia w czasie tego Wielkiego Postu, a było to na tydzień przed Wielkim Piątkiem. Dzień ten przepędziłam $\mathrm{w}$ wielkim skupieniu wewnętrznym, wyniszczając się na korzyść dusz" (Dz 640)8.

Bardzo często, śledząc treści „Dzienniczka”, można spotkać fragmenty, w których Siostra Faustyna podejmowała ofiary dla zbawienia dusz i „biednych grzeszników”. Potwierdzeniem tego niech będą niniejsze słowa:

Dziś doznałam wielkiego cierpienia w chwili odwiedzin przez nasze siostry. Dowiedziałam się o pewnej rzeczy, która mi bardzo zraniła serce, jednak opanowałam się tak, że siostry wcale nie zauważyły. Ból ten rozdzierał mi serce przez dłuższą chwilę, ale to wszystko za biednych grzeszników [...] O Jezu, za biednych grzeszników... Jezu, siło moja, bądź przy mnie, wspomóż mnie. . ." (Dz 875).

Wynika z tego, że ofiary, które składa się za grzeszników, mają przede wszystkim charakter moralny, wewnętrzny i nie muszą odnosić się do krzywdy fizycznej bądź materialnych trudności. Można zatem postawić pytanie: czemu modlitwa w intencji biednych grzeszników jest aż tak ważna? Odpowiedzi udziela sam Jezus w słowach: „Kiedy konałem na krzyżu, nie myślałem o sobie, ale o biednych grzesznikach i modliłem się do Ojca za nimi. Chcę, ażeby i ostatnie chwile twoje były zupełnie podobne do Mnie na krzyżu. Jedna jest cena, za którą się kupuje dusze - a tą jest cierpienie złączone z cierpieniem Moim na krzyżu. Miłość czysta rozumie te słowa, miłość cielesna nie pojmie ich nigdy" (Dz 324) ${ }^{10}$. Wypowiedź Chrystusa staje się swoistym zaproszeniem do pamiętania zwłaszcza w Wielkim Poście o modlitwie i ofiarowywaniu cierpień w intencji nawrócenia grzeszników.

\footnotetext{
8 Zob. też Dz 709.

9 Zob. Dz 72, 311, 356, 504, 648, 845, 908, 927, 1211, 1640, 1783, 1806.

${ }_{10}$ Por. Dz 367, 699.
} 


\section{POMOC KAPŁANOM W RATOWANIU DUSZ}

Z poprzednim zagadnieniem wypraszania nawrócenia dla dusz łączy się również pomoc kapłanom w ich ratowaniu. Mimo że św. Faustyna w sposób czynny nie pomagała kapłanom w prowadzeniu rekolekcji (nie ma wzmianek, a przynajmniej autor opracowania z żadną się nie spotkał), to nie oznacza, iż nie przyczyniła się do ratowania dusz. Właśnie w Wielkim Poście w 1937 roku, w środę popielcową, uczyniła krótki wpis do „Dzienniczka”: „Dziś środa popielcowa. W czasie Mszy św. uczułam mękę Jezusa w członkach swoich przez krótką chwilę. Wielki Post to sposób szczególny prac kapłańskich, trzeba iść im na pomoc w ratowaniu dusz" (Dz 931). Również wszelkie praktyki wielkopostne i umartwienia czyniła, „aby uprosić miłosierdzie Boże dla biednych grzeszników, a dla kapłanów moc kruszenia serc grzesznych” (Dz 934). Sam Jezus zachęcał Faustynę do takiej formy modlitwy, mówiąc: „Hostio miła Moja, módl się za kapłanów, szczególnie w tym czasie żniw” (Dz 980) ${ }^{11}$. Tak więc czas Wielkiego Postu staje się szczególnym wołaniem na dwa głosy: o osobistą modlitwę za grzeszników i nawrócenie dla dusz, a także za kapłanów, by kruszyli ich serca. W związku z tym osobista praktyka wielkopostna może realizować się w modlitwie, wyrzeczeniach i ofiarach poniesionych w wymienionych intencjach. Kapłani-rekolekcjoniści potrzebują modlitwy osób świeckich, by słowo, które będą siać, padało na żyzną glebę ludzkich serc. Warto zatem podejmować modlitwy za rekolekcjonistów, spowiedników, aby byli żywymi przekazicielami Bożego miłosierdzia oraz za tych, którzy będą przystępowali do sakramentu pokuty i pojednania (zwłaszcza za tych, którzy się wahają w tej mierze). Modlić się także za wszystkich, którzy będą uczestniczyli w rekolekcjach wielkopostnych, jak i za tych, którzy angażują się w ich przygotowanie - katechetów czy zespoły rekolekcyjne.

Do osobistej modlitwy za kapłanów można wykorzystać tę, którą ułożyła sama św. Faustyna:

O Jezu mój, proszę Cię za Kościół cały, udziel mu miłości i światła Ducha Swego, daj moc słowom kapłańskim, aby serca zatwardziałe kruszyły się i wróciły do Ciebie Panie. Panie daj nam świętych kapłanów, Ty

11 Słowo „żniwa” w potocznym języku kapłańskim oznacza czas Wielkiego Postu, a szczególnie rekolekcje i spowiedź wiernych. 
Sam ich utrzymuj w świętości. O Boski i Najwyższy Kapłanie, niech moc miłosierdzia Twego towarzyszy im wszędzie i chroni ich od zasadzek i sideł diabelskich, które ustawicznie zastawia na dusze kapłana. Niechaj moc miłosierdzia Twego, o Panie, kruszy i wniwecz obraca wszystko to, co by mogło przyćmić świętość kapłana, bo Ty wszystko możesz (Dz 1052).

\section{5. „DROBNE PRAKTYKI NA POST"}

Siostra Faustyna umartwiała się drobnymi praktykami wielkopostnymi. Było to już u schyłku jej życia, kiedy choroba nie pozwalała podejmować wielkich umartwień. Jednakże mimo słabego stanu zdrowia nie zrezygnowała $z$ drobnych przedsięwzięć, mających na celu umartwianie się. Pisze w ten sposób:

Nie mogę ćwiczyć się w wielkich umartwieniach, jak dawniej, pomimo gorącej chęci i pragnienia, ponieważ jestem pod ścisłą obserwacją lekarza, ale w drobniejszych rzeczach ćwiczyć się mogę: pierwsze - sypiać bez poduszki, trochę czuć się głodna, codziennie odmówić koronkę, której mnie nauczył Pan, z rozkrzyżowanymi rękami, czasem się pomodlić z rozkrzyżowanymi rękami przez czas nieokreślony i modlitwą niesformułowaną (Dz 934).

Wdrażając się w lekturę „Dzienniczka”, można zauważyć, że niekiedy Siostra Faustyna umartwiała swoje ciało poprzez noszenie bransoletki, czyli wąskiego, kolczastego, zapinanego łańcuszka ${ }^{12}$ oraz paska przypominającego drobną, kolczastą siatkę drucianą ${ }^{13}$. Były to formy pokutne, które praktykowała w celu umartwiania ciała. Wspominał o tym jej rodzony brat Stanisław Kowalski: „[...] gdy przyjechała już jako zakonnica do domu z powodu ciężkiej choroby matki naszej [...] miała dla siebie pokoik i nikt z nas tam nie wchodził, ale ja, wówczas szesnastoletni chłopiec, wieczorem podglądałem ją przez okno z dworu i widziałem, jak zakładała na nogi jakieś łańcuszki”14.

12 Zob. Dz 1347.

13 Zob. Dz 280, 1347

14 Wspomnienia o świętej Siostrze Faustynie, s. 33-34.

Odnośnie do takiego rodzaju praktyk pokutnych wypowiadał się św. Franciszek Salezy w słowach: „Biczowanie się, używane w miarę, jest bardzo dobrym 
Podejmując takie formy umartwiania się, należy pamiętać o ostrożności. Wszystkie poważne umartwienia typu: noszenie włosiennicy, odmawianie sobie pokarmu lub snu muszą być podyktowane roztropnością i skonsultowane z kierownikiem duchowym. Trzeba zaznaczyć, że takie praktyki mogą być niebezpieczne i przynieść odwrotny skutek. Jeśli osoba, która pracuje fizycznie, drastycznie odmówi sobie pokarmu, to nie będzie miała siły do wykonywania obowiązków. Podobnie jest ze snem. Zbyt mała jego ilość wywołuje zmęczenie, trudności w koncentracji, podenerwowanie, apatię. To wszystko spowoduje, że człowiek nie będzie mógł należycie funkcjonować, wypełniając swoje powinności. Trzeba pamiętać, że

jesteśmy przede wszystkim wezwani do dzieł miłosierdzia, a skąd weźmiemy na nie siłę, jeśli zbyt drastycznie odmówimy sobie pokarmu? Ponadto ciało poskramia nie tylko post, ale także praca, która będzie zawsze dla osoby świeckiej pierwszym narzędziem formacji i umartwienia. Jeśli brakuje sił potrzebnych do jej wykonania, bo przesadziliśmy z praktykami pokutnymi, wycofujemy się z nich ${ }^{15}$.

W związku z tym w tego rodzaju praktykach należy kierować się umiarem i roztropnością. Osoba, zamiast nakładać na siebie wymagające posty, może jeść odrobinę mniej niż domaga się tego apetyt ${ }^{16}$, odmówić sobie popołudniowej drzemki albo myć się w wodzie o nieco niższej temperaturze niż zazwyczaj się preferuje. Oprócz tego umartwienie może dotyczyć braku narzekania, kiedy podejmuje się trud pracy zawodowej,

środkiem rozbudzania $\mathrm{w}$ nas pragnienia wyższej pobożności. Włosiennica także dzielnie hamuje ciało, ale jej używanie nie jest zwykle stosowne ani dla tych, co żyją w małżeństwie, ani dla tych, co są słabego zdrowia, ani wreszcie dla tych, co wystawieni są na ciężkie prace i trudy”. F. Salezy, Filotea czyli droga do życia pobożnego, rozdz. O ćwiczeniach umartwienia zewnętrznego.

15 E. Wiater, Filotea. Duchowość dla świeckich 2.1, Kraków 2012, s. 106.

${ }^{16}$ Inny sposób umartwienia związany z pokarmem dał Siostrze Faustynie jej spowiednik: „Na początku postu prosiłam swego spowiednika o umartwienie na ten okres postu i otrzymałam takie, abym nie ujmowała sobie pokarmów, ale kiedy będę spożywać - mam rozważać, tak Pan Jezus przyjął na krzyżu ocet z żółcią: to będzie jako umartwienie. Nie wiedziałam, że tak wielką korzyść będę czerpać dla duszy swojej. Korzyść ta jest, że ustawicznie rozważam Jego bolesną mękę, i wtenczas kiedy spożywam pokarmy, nie rozróżniam co spożywam, ale jestem zajęta śmiercią Pana Swego" (Dz 619). 
zwłaszcza gdy odczuwa się zniechęcenie. Umartwianie to również solidne wykonywanie własnych obowiązków wynikających ze stanu i funkcji (małżeńskiej, rodzicielskiej), ale również poskramianie lenistwa, niespóźnianie się na umówione spotkanie, dotrzymywanie danego słowa, zwłaszcza kiedy warunki są niekorzystne. To umartwianie swojej ciekawości, kiedy pohamowuje się chęć pytania o szczegóły ${ }^{17}$. Przytoczone przykłady z całą pewnością stanowią wartą rozważenia formę umartwienia i kto wie, czy nie trudniejszą do wykonania niż noszenie włosiennicy ${ }^{18}$.

\section{ZNOSZENIE W POKORZE CIERPIENIA I PRZYJMOWANIE Z MIŁOŚCIĄ WSZYSTKIEGO, CO DAJE BÓG}

Kolejna wskazówka, którą daje św. Siostra Faustyna na przeżywanie Wielkiego Postu, dotyczy umiejętności cierpienia. Jest to temat niełatwy, gdyż nie zawsze człowiek godzi się z trudnościami, na jakie napotyka w życiu. Rodzaje cierpień mogą mieć różny charakter. Może to być cierpienie fizyczne, ból, choroba, niepełnosprawność, ale również cierpienie duchowe, moralne: znoszenie obmowy, kłamstwa na nasz temat, odbieranie nam dobrego imienia (zob. Dz 1685), pomówienia, samotność, niezrozumienie, posądzenie, złośliwość, złe traktowanie przez bliskich lub przełożonych. Na takie sytuacje Jezus daje jedno lekarstwo zawarte w słowach, które skierował do św. Faustyny:

Uczennico Moja, miej wielką miłość do tych, którzy ci zadają cierpienie, czyń dobrze tym, którzy cię nienawidzą. Odpowiedziałam: o mój Mistrzu, przecież Ty widzisz, że nie mam uczucia miłości dla nich i to mnie martwi. Jezus mi odpowiedział: Uczucie nie zawsze jest $\mathrm{w}$ twej mocy, poznasz po tym, czy masz miłość, jeżeli po doznanych przykro-

17 „Jedna z sióstr się wyraziła: ja tak czekam, kiedy też Pan Jezus Siostrę zabierze, bo wiem co to będzie i bardzo pragnę śmierci dla siostry. Jednak chciałam się zapytać, co ona myśli o mojej śmierci, ale umartwiłam się i odpowiedziałam: to będzie, ze mną grzesznicą, co ze wszystkimi grzesznikami, jeżeli mnie nie osłoni miłosierdzie Boże" (Dz 1673).

18 Por. J. L. Lorda, Być chrześcijaninem. Poradnik ewangelicznego życia, Poznań 2011, s. 65. 
ściach i przeciwnościach nie tracisz spokoju, ale modlisz się za tych, od których doznałaś cierpienia i życzysz im dobrze (Dz 1628) ${ }^{19}$.

Należy zauważyć i podkreślić, że świętej Siostry Faustyny, mimo że była w szczególny sposób wybrana przez Boga, nie omijały różnego rodzaju cierpienia. Śledząc jej życie, można powiedzieć, że znosiła je w sposób heroiczny. Czyniła to dla Jezusa, łącząc swoje cierpienia z Jego męką. Tak pisze w „Dzienniczku”:

Rozpoczęłam post święty tak, jak sobie życzył Jezus, zdając się całkowicie na Jego świętą wolę i przyjmując wszystko z miłością cokolwiek mi poda. Nie mogę praktykować większych umartwień, bo jestem bardzo słaba. Dłuższa choroba wyniszczyła mi zupełnie siły. Łączę się z Jezusem przez cierpienie. Kiedy rozważam Jego bolesną Mękę, to zmniejszają się moje fizyczne cierpienia. Powiedział mi Pan: Zabieram cię na cały post do swej szkoły, chcę cię nauczyć cierpieć. Odpowiedziałam: z Tobą Panie jestem gotowa na wszystko, i usłyszałam głos: Wolno ci pić z kielicha z którego Ja piję; ten wyłączny zaszczyt daję ci dziś... (Dz 1625-1626).

Życie św. Faustyny było naznaczone ogromem cierpień, które przeżywała z miłości do Jezusa i do bliźnich (zwłaszcza tych trudnych) ${ }^{20}$.

19 Inny przykład cierpienia duchowego: „Kiedy w jednym dniu czułam, że nie dam rady wychodzić do dziewiątej i prosiłam s. N. o trochę co zjeść, bo idę wcześniej się położyć, dlatego, że się źle czuję, s. N. odpowiedziała mi: A siostra nie jest chora, tylko chcieli siostrze dać wypoczynek i dlatego upozorowali chorobę. O mój Jezu, przecież choroba się posunęła tak daleko, że lekarz mnie odseparował od sióstr, aby się nie udzieliła innym, a tu jednak człowiek jest tak sądzony, ale to dobrze, to wszystko dla Ciebie, Jezu mój” (Dz 710).

${ }^{20}$ Siostra Faustyna wiele musiała znieść cierpień i przykrości od współsióstr, które nie rozumiały jej duchowości. Między innymi z tego względu nie darzyły jej sympatią, co miało odzwierciedlenie w wyśmiewaniu jej, obmowach, stronieniu od niej bądź upokarzaniu. Przykładem tego są fragmenty z „Dzienniczka”: „Dziś sprzątałam pokój jednej z sióstr. Pomimo że się starałam go sprzątać z największym staraniem, jednak osoba ta przez cały czas sprzątania chodziła za mną i mówiła - tu proszek, tam plamka na podłodze. Na każde jej skinienie poprawiałam choć dziesięć razy to samo, byle ją zadowolić. Nie praca męczy, ale te nieumiarkowane gadania i wymagania. Nie wystarczyło jej moje całodzienne męczeństwo, ale poszła do Mistrzyni na skargę. Proszę Matki, co to za siostra niedokładna, nie umie się pospieszać. Na drugi dzień poszłam tę samą robotę robić bez słowa tłumaczenia. Kiedy mnie wzięła w swoje obroty, to pomyślałam 
Niejednokrotnie swoje cierpienia ofiarowywała za grzeszników (np. Dz 72, 206, 246, 280, 308, 309, 319, 349, 384, 648), dusze cierpiące w czyśćcu (Dz 58, 240, 274, 346, 412, 692, 1226, 1723, 1738) bądź wprost cierpienia innych brała na siebie (Dz 41, 163, 192, 291, 311). Podczas obłóczyn, czyli obrzędu ubierania habitu po raz pierwszy, Jezus dał poznać Faustynie, ile będzie musiała cierpieć ( $\mathrm{Dz} 22)^{21}$. Niemniej każde cierpienie Faustyna przyjmowała $\mathrm{w}$ pokorze i $\mathrm{z}$ ochotą serca, nie zrażając się ich wielkością wymagającą poświęcenia $\mathrm{z}$ aktami pokuty i umartwień. Jej cierpienie było ściśle związane z miłością do Chrystusa, o czym mogą świadczyć słowa:

Kiedy raz miałam jedno cierpienie wielkie, uciekałam od obowiązku do Pana Jezusa i prosiłam, aby mi udzielił swej mocy. Po króciutkiej modlitwie wróciłam do obowiązku pełna zapału i radości. W tym mi mówi

sobie: Jezu, można być cicha męczennicą - nie od pracy sił ubywa, ale tego męczeństwa" (Dz 181). Zob. też Dz 29, 128, 151, 165, 167-168, 171, 172.

Przykładami innych przykrości i umartwień są świadectwa o św. Faustynie złożone przez siostrę Sylwestrę Domińską: „Jak jej dano pończochy ciepłe i pocerowane bardzo $\mathrm{w}$ lecie, to powiedziała $\mathrm{z}$ uśmiechem, że jak się nie uświęcić? W zimie to dawano cienkie”; „Robiono porządki w sypialni, potem zawieszano firanki, wszystkie cele zasłonięto, a Siostry Faustyny zostawiono, że zabrakło firanki. Ona gdy weszła do sypialni, to jej powiedziano, że «dla siostry braknie firanki». Popatrzyła się z uśmiechem po wszystkich celach i odpowiedziała: «Dobrze, ja kocham święte ubóstwo, proszę mi nie wieszać, jeżeli brakuje». I tak spała kilka tygodni... do wyjazdu. Ale na noc to się zasłaniała kocem i kapą, a jak się szła położyć po obiedzie, to wchodziła do innej celi”. Wspomnienia o świętej Siostrze Faustynie, s. 225-226. Natomiast siostra Szymona Nalewajk wspomina o Siostrze Faustynie: „Byłyśmy razem w nowicjacie. Jako postulantka miała tak niewygodne obuwie, że nogi w ranach kapały krwią. Widziałam, jak ledwie idąc po schodach klękała, i całowała je. Nie chciała prosić o inne [buty] - wolała cierpieć. Ja o tym powiedziałam siostrze Zuzannie i dała jej inne obuwie”. Tamże, s. 227.

${ }^{21}$ Podczas obłóczyn i pod wpływem wizji o przyszłych cierpieniach siostra Faustyna zemdlała. Świadkiem tego zdarzenia była siostra M. Klemensa Buczek, która pomagała Faustynie przy ubiorze habitu. Tak wspomina to wydarzenie: „«Helenko, spieszmy się, zdejmujmy tę suknię, aby włożyć habit. Bierzmy się do roboty». Helenka zemdlała, pobiegłam po wodę kolońską. Gdy wróciłam, ona już ocuciła się trochę, spieszyć trzeba, więc mówię: «No, Helenko, ucałować mocno ten habit, żebyś w nim do śmierci Panu Jezusowi służyła». Ucałowała serdecznie, a ja jej jeszcze dokuczałam w żartach: «Tak za światem żałuję, że aż mdleje!». I śmiałyśmy się trochę obie”. Tamże, s. 184. Na temat cierpienia zob. też Dz 36, 73, 104, 190, 192, 488, 675, 918, 1626. 
jedna z sióstr, że pewno siostra dziś ma wiele pociech, bo taka siostra jest rozpromieniona. Bóg pewno siostrze nie daje żadnego cierpienia - tylko same pociechy. Odpowiedziałam - myli się siostra bardzo, bo właśnie wtenczas, kiedy wiele cierpię, to i radość moja większa, a kiedy mniej cierpię, to i radość moja mniejsza. Jednak ta dusza dawała mi poznać, że mnie w tym nie rozumie. Starałam się jej to wytłumaczyć: kiedy cierpimy wiele, to mamy sposobność wielką okazać Bogu, że Go kochamy, a kiedy cierpimy mało, to mamy mało sposobności, by okazać Bogu swą miłość, a kiedy nie cierpimy nic, to miłość nasza nie jest wielka ani czysta. Możemy dojść za łaską Bożą do tego, że cierpienie dla nas zamieni się w rozkosz, bo miłość umie takie rzeczy działać w duszach czystych. (Dz 303)

Analizując jej życie, można zauważyć, iż wszelkie formy cierpień stały się dla Faustyny stałymi towarzyszkami (zob. Dz 316).

Czas Wielkiego Postu może przysłużyć się do wydoskonalania się w cnocie związanej z przyjmowaniem cierpień i przeżywania ich w duchu wiary i zaufaniu Bogu. Dotyczy to zarówno cierpień trudnych, wymagających, jak i tych małych, związanych z jakimiś niedogodnościami bądź psychicznym dyskomfortem. W tym wszystkim należy upatrywać wolę i dopust Boży i prosić, by przyjmować je z pokorą. W ten sposób kształtuje się w człowieku zaufanie względem Boga i dzięcięctwo, kiedy powierza się jako bezbronne dziecko swojemu miłosiernemu Ojcu. Faustyna była i wciąż staje się wzorowym przykładem takiego zawierzenia ${ }^{22}$.

${ }^{22}$ Należy pamiętać, że Pan Bóg w swojej mądrości posługuje się sytuacjami trudnymi, by kształcić wnętrze duchowe człowieka. Siostra Faustyna przez złośliwości innych sióstr wykształciła się na przykład w cnocie cierpliwości: „Kiedy się żegnałam z siostrami i już miałam odjechać, jedna z Sióstr bardzo mnie przepraszała, że mi tak mało dopomagała w obowiązku i, że nie tylko mi nie dopomagała, ale że się starała zawsze utrudniać. Jednak ja ją w duszy uważałam za dobrodziejkę wielką, bo wyćwiczyła mnie w cierpliwości; do tego stopnia mnie ćwiczyła, że jedna ze starszych sióstr wyraziła się tak, że siostra Faustyna to albo głupia, albo święta, bo naprawdę przeciętny człowiek nie zniósłby tego, żeby tak ktoś stale robił na przekór. Ja jednak zawsze zbliżałam się do niej z życzliwością. Starała się ta pewna siostra tak utrudniać mi pracę w obowiązku, tak, że pomimo mojego wysiłku, udało się jej nieraz coś zepsuć z tego, co było dobrze zrobione, jako mi sama przy pożegnaniu zeznała, przepraszając mnie bardzo. Nie chciałam wnikać w intencje jej, ale brałam to jako doświadczenie Boże” (Dz 632). 


\section{PODDAWANIE SIĘ WOLI BOŻEJ KORONĄ WSZELKICH POSTÓW I UMARTWIEŃ}

Wczytując się w bogactwo „Dzienniczka”, można zauważyć, że głównym elementem życia duchowego św. Siostry Faustyny jest całkowite poddanie się woli Bożej i jej realizacja. Jest to wątek najważniejszy, na którym bazują wszystkie inne. Bóg zdziałał tak wiele przez osobę i życie Faustyny dlatego, że ona była Mu całkowicie oddana i posłuszna. Pokarmem było dla niej pełnienie Bożej woli - tylko to dla niej się liczyło i było najistotniejsze. Świadczących o tym fragmentów z „Dzienniczka” jest bardzo dużo. Niech chociaż niektóre staną się tego świadectwem ${ }^{23}$ : „Wierne poddawanie się zawsze i wszędzie woli Bożej, we wszystkich wypadkach i okolicznościach życia, oddaje Bogu wielką chwałę; takie poddanie się woli Bożej, większą ma w Jego oczach wagę niż długie posty, umartwienia i najsurowsze pokuty. $\mathrm{O}$, jak wielka jest nagroda za jeden akt miłosnego poddania się woli Boga. Pisząc to, w zachwyt dusza moja wpada, jak ją Bóg miłuje, a jakim pokojem już tu na ziemi dusza się cieszy" (Dz 724); „W czasie rozmyślania usłyszałam te słowa: Córko Moja, największą oddajesz Mi chwałę, przez cierpliwe poddawanie się woli Mojej, a sobie skarbisz tak wielką zasługę, że ani postami, ani żadnymi umartwieniami nie osiągnęłabyś tego. Wiedz o tym, córko Moja, że jeżeli wolę swoją poddajesz pod wolę Moją, ściągasz na siebie wielkie upodobanie Moje, ta ofiara jest Mi miła i pełna słodkości, w niej sobie podobam, ona ma moc” (Dz 904); „Pierwszy piątek miesiąca. Po Komunii św. nagle ujrzałam Pana Jezusa, który mi rzekł te słowa: Teraz wiem, że nie dla łask, ani darów Mnie miłujesz, ale wola Moja droższa ci jest niż życie; dlatego łączę się z tobą tak ściśle, jako z żadnym stworzeniem" (Dz 707).

Podsumowując powyższe rozważania, należy zaznaczyć, iż przytoczone sposoby przeżywania Wielkiego Postu wiążą się w ścisły sposób

${ }^{23}$ Inne fragmenty mówiące o doniosłości pełnienia woli Bożej: Dz 6, 73, 78, 88, 136, 365, 372, 374, 443, 634, 707, 904, 954, 1023, 1184. Przykładem bezgranicznego posłuszeństwa, jakie miała św. Faustyna względem Jezusa i szukania Jego woli, jest fragment listu zakonnicy do jej spowiednika ks. Michała Sopoćki: „Jeszcze parę słów pragnę Drogiemu Ojcu, powiedzieć, ponieważ list ten napisałam 11 kwietnia, ale wysyłam dopiero 15 kwietnia, dlatego że czekałam na wyraźną wolę Bożą czy wysłać, czy nie”. Listy świętej Siostry Faustyny, wyd. 2, Kraków 2005, s. 82. 
z życiem św. Siostry Faustyny. Oznacza to, że nikt nie ma obowiązku kopiowania jej zachowań, pokutnych i ascetycznych praktyk czy wyrzeczeń. Każdy chrześcijanin ma swoją drogę do poznania i pokochania Boga, zbudowania z Nim relacji i osiągnięcia świętości. Święta Faustyna miała swoją. Oczywiście można czerpać z niej przykład i wykorzystać jej wskazówki, modyfikując do swojej sytuacji życiowej. Jedno jest pewne - najważniejsze to szukanie woli Boga i jej realizacja. Efektem takiego postępowania będzie to, co napisała o Faustynie siostra Klemensa Buczek: „Widać w niej było głębokie zjednoczenie z Panem Jezusem, serce jej biegło do Niego" ${ }^{24}$. Można powiedzieć, że celem przyświecającym podejmowanym decyzjom $\mathrm{w}$ życiu osobistym powinno być dążenie do zjednoczenia z Bogiem.

Warto również zaznaczyć, że Siostra Faustyna może stać się szczególną przewodniczką dla każdego wierzącego i to nie tylko na czas Wielkiego Postu, ale w całej rozciągłości życia.

Każdy wierzący powinien odnaleźć w ogromnej rzeszy świętych tego, który ze względu na swoje życie, pisma czy dokonania jest mu bliższy. Z doświadczenia duszpasterskiego wynika, iż takie przylgnięcie do konkretnej kanonizowanej lub beatyfikowanej osoby przynosi ogromny pożytek. „Można powiedzieć, że przyjaźnie ze świętymi przynoszą owoce, umacniają wiarę. Nieraz zaskakuje nas taka konkretność ich działania. [...] Wstawiennictwo świętych jest powszechnym dobrem Kościoła, jest ono dla wszystkich. Nie każdy jednak wie o tym, że może i powinien zwracać się do świętych. I tu nasza rola, abyśmy dzielili się jak najczęściej prostym świadectwem naszej relacji ze świętymi” ${ }^{25}$.

Autor wyraża nadzieję, że niniejsze rozważanie przyczyni się do nawiązania przez czytelnika bliskich relacji ze św. Siostrą Faustyną, dzięki której pogłębią się więzi ze Zbawicielem. Niech czas Wielkiego Postu temu służy i będzie owocnie wykorzystany.

24 Wspomnienia o świętej Siostrze Faustynie, s. 185.

25 J. Mastalski, Modlitwa kapłańska, wyd. 2, Kraków 2014, s. 41-42. 
Streszczenie. Okres Wielkiego Postu to szczególny czas, jaki daje Kościół. Podczas niego wierni podejmują postanowienia, wyrzeczenia i wysiłek pracy nad sobą. Często wyrzeczenia odnoszą się do wymiaru materialnego: odmówienie sobie przyjemności, ograniczenie posiłku czy oglądania telewizji. Inna forma odnosi się do wymiaru duchowego, który wiąże się między innymi z pracą nad własnymi wadami, niedoskonałościami charakteru bądź pogłębieniem życia duchowego ${ }^{26}$. Praktyka duszpasterska wskazuje, że niekiedy wiernym brakuje pomysłów, w jaki sposób spożytkować i dobrze wykorzystać czas Wielkiego Postu. Celem niniejszego rozważania jest podanie wskazówek i propozycji do jego przeżycia na podstawie przykładu św. Siostry Faustyny, które zapisała w „Dzienniczku”. Oto niektóre z nich: modlitwa, adoracja i dzielenie się z Bogiem codziennością; pokonywanie trudności w modlitwie i w relacjach z innymi; wypraszanie nawrócenie dla dusz oraz pomoc kapłanom w ich ratowaniu; znoszenie w pokorze cierpienia i przyjmowanie z miłością wszystkiego, co daje Bóg; poddawanie się woli Bożej jako korona wszelkich postów i umartwień.

Słowa kluczowe: św. s. Faustyna; Wielki Post; postanowienia; asceza; umartwienie.

Abstract. Requirements to Experience the Lent According to Saint Sister Faustina. The period of Lent is a special time given by the Church. During Lent the faithful make resolutions, abstain and make an effort to work on their self-improvement. Frequently, renunciation refers to the material dimension, such as refraining from pleasure, limiting food or watching television. Another form of sacrifice refers to the spiritual dimension which is linked with self-improvement, realizing one's faults and imperfections of character or spiritual development. Pastoral practice indicates that sometimes the faithful lack ideas how to use the time of Lent. The aim of this reflection is to provide some indication and offer suggestions how to experience Lent relying on the examples provided by Saint Sister Faustina in her Diary. Here are some of them: prayer, adoration and sharing with God your everyday life; overcoming difficulties in prayer and in relations with other people, praying for the conversion of sinners and help for clergymen in

${ }^{26}$ Zagłębiając się w tematykę, można pokusić się o stwierdzenie, że postanowienia duchowe mają głębszy wymiar niż materialne. Nie oznacza to, że materialne są mniej ważne bądź łatwiejsze od realizacji - jest to raczej sprawa subiektywna, związana z konkretną osobą. Niemniej często zdarza się, iż postanowienia materialne zostają zawieszone wraz z końcem Wielkiego Postu, natomiast duchowe trwają nadal. Dziwne by było, gdyby przez okres Wielkiego Postu osoba byłaby uprzejma, a po skończonym okresie pokutnym znów powróciła do swojego dawnego zachowania i brnęła w nieuprzejmość. Należy również zaznaczyć, że niniejsze propozycje przeżywania Wielkiego Postu na podstawie życia św. Siostry Faustyny nie muszą być wykonywane wyłącznie w tym okresie liturgicznym. Z powodzeniem mogą być realizowane w ciągu całego roku. 
saving the lost souls; the humble bearing of suffering and receiving everything that God gives us with love, accepting God's will as the crowning of all fasts and mortifications.

Key words: St Sr Faustina; Lent; resolutions; asceticism; mortification.

\section{BIBLIOGRAFIA}

Św. Siostra Faustyna Kowalska, „Dzienniczek”.

Czaczkowska E. K., Siostra Faustyna. Biografia Świętej, Kraków 2012.

Franciszek Salezy, Filotea czyli droga do życia pobożnego, rozdz. O ćwiczeniach umartwienia zewnętrznego, Kraków 2000.

Lorda J. L., Być chrześcijaninem. Poradnik ewangelicznego życia, Poznań 2011.

Mastalski J., Modlitwa kapłańska, wyd. 2, Kraków 2014.

Wiater E., Filotea. Duchowość dla świeckich 2.1, Kraków 2012, s. 106.

Wspomnienia o świętej Siostrze Faustynie Kowalskiej ze Zgromadzenia Matki Bożej Miłosierdzia, wyd. 2, Kraków 2015. 